\title{
Latitudinal patterns in the abundance of major marine bacterioplankton groups
}

\author{
Matthias Wietz ${ }^{1, *}$, Lone Gram ${ }^{1}$, Bo Jørgensen', Andreas Schramm² \\ ${ }^{1}$ National Food Institute, Technical University of Denmark, 2800 Kgs. Lyngby, Denmark \\ ${ }^{2}$ Department of Biological Sciences, Microbiology, Aarhus University, 8000 Aarhus, Denmark
}

\begin{abstract}
The present study describes the abundance of major marine bacterioplankton groups and 2 bacterial genera (Pseudoalteromonas and Vibrio) in surface seawater at 24 stations around the world. Catalyzed reporter deposition-fluorescence in situ hybridization showed that Alphaproteobacteria (average relative abundance $37 \%$, average absolute abundance $3.7 \times 10^{5}$ cells ml $^{-1}$ ) including SAR11 [30\% / $\left.\left(3 \times 10^{5}\right)\right]$, Gammaproteobacteria $\left[14 \% /\left(1.2 \times 10^{5}\right)\right]$ and Bacteroidetes $[12 \% /$ $\left.\left(1.3 \times 10^{5}\right)\right]$ globally dominated the bacterioplankton. The SAR86 clade $\left[4.6 \% /\left(4.1 \times 10^{4}\right)\right]$ and Actinobacteria $\left[4.5 \% /\left(4 \times 10^{4}\right)\right]$ were detected ubiquitously, whereas Archaea were scarce $[0.6 \% /(4.2 \times$ $\left.\left.10^{3}\right)\right]$. The Roseobacter clade [averaging $\left.3.8 \% /\left(3.5 \times 10^{4}\right)\right]$, Pseudoalteromonas $\left[2.6 \% /\left(2.1 \times 10^{4}\right)\right]$ and Vibrio $\left[1.5 \% /\left(1.3 \times 10^{4}\right)\right]$ showed cosmopolitan occurrence. Principal component analysis revealed a latitudinal pattern in bacterial abundances by clustering samples according to lower and higher latitudes. This was related to significantly different relative abundances of Bacteroidetes (peaking at higher latitudes) and of unclassified Bacteria and Vibrio (both peaking at lower latitudes) between warmer and colder oceans. Relative abundances of Alphaproteobacteria (peaking at subtropical) and Gammaproteobacteria (polar stations) varied between major oceanic biomes, as did absolute abundances of Roseobacter (peaking at temperate and polar stations). For almost all groups, absolute abundances were positively correlated with nutrient concentrations in warmer oceans and negatively correlated with oxygen saturation in colder oceans. On a global scale, Roseobacter and SAR86 were correlated with chlorophyll $a$. Linkages of environmental parameters with relative abundances were more complex, with e.g. Bacteroidetes being associated with chlorophyll $a$. The finding of differing communities in warmer and colder oceans underlined the presence of biogeographical patterns among marine bacteria and the influence of environmental parameters on bacterial distribution.
\end{abstract}

KEY WORDS: Marine bacterioplankton · Global quantification · Latitudinal pattern · Biogeography · CARD-FISH $\cdot$ PCA

\section{INTRODUCTION}

The diversity, activity and ecology of marine microbes - the main form of biomass in the oceans have become key research subjects over the previous years, greatly expanding our knowledge of the structure and function of marine microbiota (Giovannoni \& Stingl 2005). Given the role of marine bacteria in global nutrient turnover, biogeochemical processes and climate events (Arrigo 2005), the study of microbial distri- bution and biogeography has received increasing attention (Martiny et al. 2006). Still, there is only a basic understanding of marine bacterial community structure on a global scale, such as to whether 'everything is everywhere, but the environment selects' (BaasBecking 1934) or if geographically separated regions harbour distinct communities. This discussion also addresses the relation of environmental factors to spatial and temporal patterns among bacteria (Dolan 2005, Martiny et al. 2006, Van der Gucht et al. 2007). 
Characterization of marine bacterial communities on larger geographical scales has been done by shotgun sequencing (Rusch et al. 2007), polymerase chain reaction (PCR)-based techniques (Baldwin et al. 2005, Pommier et al. 2007, Taniguchi \& Hamasaki 2008) and catalyzed reporter deposition-fluorescence in situ hybridization (CARD-FISH) (Schattenhofer et al. 2009). These studies have indicated that the composition of bacterioplankton differs between oceanic regions, probably related to oceanographic factors such as water temperature (Baldwin et al. 2005, Fuhrman et al. 2008), nutrient availability (Abell \& Bowman 2005), or water masses (Teira et al. 2006, Galand et al. 2010). The analysis of a global sample set showed marked variation in bacterial community structure on the 16S rRNA sequence level, with a high degree of endemism and few cosmopolitan sequences (Pommier et al. 2007). A latitudinal gradient in species richness, comparable to observations in the animal and plant kingdoms, has been shown in this context (Pommier et al. 2007, Fuhrman et al. 2008). Terminal-restriction fragment length polymorphism (T-RFLP) demonstrated distinct microbial clusters relating to Arctic, Antarctic, temperate and tropical regions, with mid-latitudinal and equatorial communities being more similar in composition to each other than to cold water communities (Baldwin et al. 2005). Quantitative analyses showed that across an Atlantic Ocean transect, SAR11 was more abundant in the northern Atlantic Ocean than in the southern Atlantic gyre, the biomass of Prochlorococcus peaked in the tropical Atlantic Ocean, and Bacteroidetes and Gammaproteobacteria bloomed in nutrient-rich temperate waters (Schattenhofer et al. 2009). Furthermore, prokaryotic assemblage structure was shown to exhibit strong variability along estuarine gradients (Kirchman et al. 2005), coast-ocean transitions (Baltar et al. 2007) and ocean fronts (Pinhassi et al. 2003).

The present study adds to the understanding of marine bacterial biogeography by analyzing bacterioplankton community structure and environmental parameters along the route of the worldwide Galathea 3 expedition. The Earth's circumnavigation included both a global survey of culturable bacteria with antibacterial activity (Gram et al. 2010) and a cultivation-independent investigation of bacterioplankton by CARD-FISH. This enabled the direct quantification of domains (Bacteria and Archaea), higher phylogenetic groups (Alpha- and Gammaproteobacteria, Bacteroidetes, Actinobacteria), important bacterial clades (SAR11, SAR86, Roseobacter) and 2 individual genera (Pseudoalteromonas and Vibrio). Roseobacter, Pseudoalteromonas and Vibrio were selected, since $>90 \%$ of the antagonistic strains isolated during the culturebased survey (Gram et al. 2010) were affiliated with one of the 3 groups. The purpose of the present study was to investigate potential patterns in their in situ distribution. While species cluster distribution of the Roseobacter clade has been studied (Selje et al. 2004), the biogeography of Pseudoalteromonas (Skovhus et al. 2007) and Vibrio (Thompson et al. 2006) in pelagic marine ecosystems is poorly documented.

We analyzed CARD-FISH and environmental data by principal component analysis (PCA), a statistical tool to identify patterns, associations between factors and underlying causative links within a complex dataset (Martens \& Martens 2001). PCA has been used for bacterial community analyses (Sekiguchi et al. 2002, Teira et al. 2008) and served here to investigate global patterns in the bacterioplankton community structure and their relation to environmental parameters. This contributes to the understanding of marine bacterial biogeography and the factors that influence microbial distribution on a global scale.

\section{MATERIALS AND METHODS}

Sampling procedures. At 24 stations along the route of Galathea 3 (www.galathea3.dk/uk), surface seawater was sampled using Niskin bottles on an SBE32 rosette (Seabird) connected with a conductivitytemperature-depth (CTD) profiler (MacArtney). Sampling sites covered different oceanic regions, including coastal and pelagic waters (Fig. 1, Table S1 in the supplement at www.int-res.com/articles/suppl/ a061p179_supp.pdf). Using a $5 \times 100 \mathrm{ml}$ filtration manifold (DHI LAB) 5 samples were prepared per station. Each $50 \mathrm{ml}$ seawater sample was filtered through $5 \mu \mathrm{m}$ polycarbonate filters (diameter: $25 \mathrm{~mm}$ ) to remove particle-associated bacteria. Planktonic cells were collected from the $5 \mu \mathrm{m}$ filtered water on $0.2 \mu \mathrm{m}$ polycarbonate filters (diameter: $25 \mathrm{~mm}$ ) and fixed with $2 \%$ paraformaldehyde for $1 \mathrm{~h}$ in the dark. Filters were washed with $1 \times$ phosphate-buffered saline (PBS) and sterile Milli-Q water for $1 \mathrm{~min}$ each, air dried and stored at $-80^{\circ} \mathrm{C}$ until further processing. A range of physicochemical environmental parameters were measured by standard methods at each station at which bacterioplankton was sampled. These included (1) oceanographic data (temperature, salinity, density, in vivo fluorescence, photosynthetically active radiation); (2) oxygen concentration and saturation; (3) concentrations of inorganic nutrients (total inorganic nitrogen [N] and phosphorus $[\mathrm{P}]$, nitrite $\left[\mathrm{NO}_{2}^{-}\right]$, nitrate $\left[\mathrm{NO}_{3}{ }^{-}\right]$, ammonium $\left[\mathrm{NH}_{4}{ }^{+}\right]$, phosphate $\left[\mathrm{PO}_{4}^{-}\right]$, silica $\left.\left[\mathrm{SiO}_{2}\right]\right)$; and (4) the concentration of chlorophyll a (Table S1).

Selection of oligonucleotide FISH probes. Bacterioplankton communities were characterized using a range of horseradish peroxidase-labelled FISH probes (Table S2 in the supplement at www.int-res.com/ 


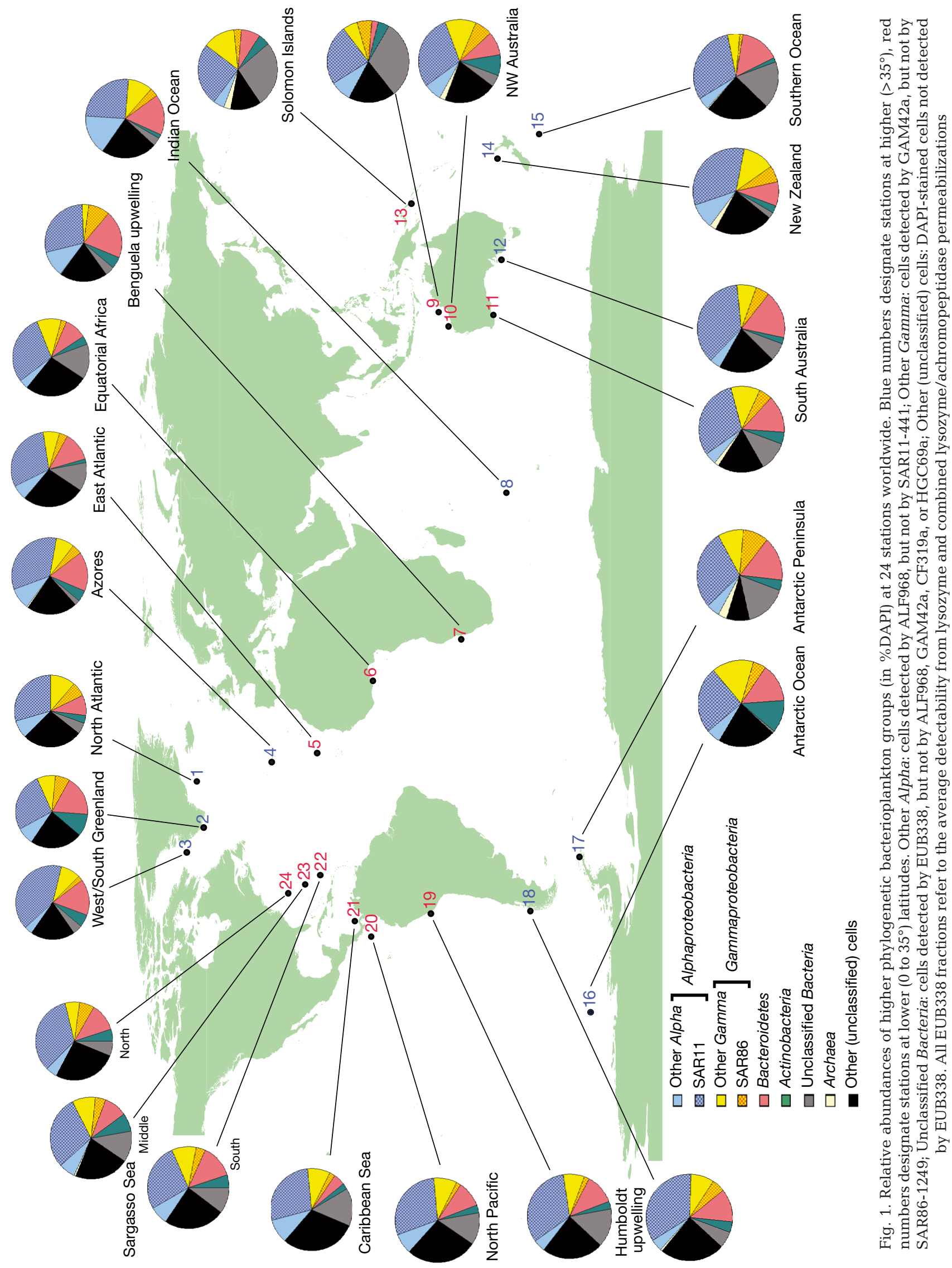


articles/suppl/a061p179_supp.pdf) purchased from biomers. net. All clade- and group-specific probes (SAR11-441, SAR86-1249, ROS536, PSU730, GV) were checked for specificity and coverage of their target groups against the SILVA database, release 96 (Pruesse et al. 2007), using the ARB software package (Ludwig et al. 2004).

CARD-FISH. Cells on filters were permeabilized by different enzyme treatments depending on the subsequent hybridization. For hybridizations targeting Bacteria, Proteobacteria and Bacteroidetes, cells were permeabilized with lysozyme $\left(10 \mathrm{mg} \mathrm{ml}^{-1}\right.$ in $1 \times$ TE buffer [0.01 M EDTA, 0.1 M Tris-HCl, pH 8.0]) for $60 \mathrm{~min}$ at $37^{\circ} \mathrm{C}$. For hybridizations targeting Bacteria and Actinobacteria, cells were permeabilized for 30 min with achromopeptidase $\left(60 \mathrm{U} \mathrm{ml}^{-1}\right.$ in $0.01 \mathrm{M} \mathrm{NaCl}, 0.01 \mathrm{M}$ Tris- $\mathrm{HCl}$, pH 8.0), followed by $30 \mathrm{~min}$ with lysozyme (1 mg ml ${ }^{-1}$ in $1 \times$ TE buffer) at $37^{\circ} \mathrm{C}$ (Sekar et al. 2003). For hybridizations targeting Archaea, cells were permeabilized with Proteinase $\mathrm{K}\left(2 \mu \mathrm{g} \mathrm{ml}^{-1}\right.$ in $1 \times \mathrm{TE}$ buffer $)$ for $60 \mathrm{~min}$ at $37^{\circ} \mathrm{C}$ (Teira et al. 2004). Filters were stored at $-20^{\circ} \mathrm{C}$ until further processing. CARD-FISH was carried out according to Pernthaler et al. (2004) using FITC-labelled tyramides for signal amplification.

Epifluorescence microscopy. Stained filter sections were inspected on an Axiovert 200M inverse fluorescence microscope (Carl Zeiss) equipped with $63 \times$ and 100× objective lenses and Filter Sets 02 (Cat. No. 488002-0000-000) for DAPI and 10 (Cat. No. 4880100000-000; both Carl Zeiss) for FITC. Per hybridization, from 600 to 1000 DAPI-stained cells were counted in $\geq 10$ microscopic fields that were randomly selected across the filter section. Relative fractions of bacterial groups were corrected by subtraction of negative control counts with probe NON338. To validate reproducibility of hybridizations and accuracy of counts, a selection of samples from widely separated stations was again hybridized with probes targeting higher phylogenetic groups. Deviations in detected relative fractions were $\leq 3 \%$, which was considered acceptable.

Data analysis. PCA was performed to reduce the complexity of multivariate data (prokaryotic abundances and physicochemical environmental parameters) in order to identify variables accounting for most of the variability in the original data. PCA was performed for each of the following datasets: (1) relative prokaryotic abundances, (2) relative abundances and environmental parameters, (3) absolute abundances and (4) absolute abundances and environmental parameters. Input data were the abundances of Actinobacteria; Bacteroidetes; SAR11, Roseobacter, other Alphaproteobacteria (difference between the sum of SAR11 and Roseobacter to the total abundance of Alphaproteobacteria); SAR86, Pseudoalteromonas, Vibrio, other Gammaproteobacteria (difference be- tween the sum of SAR86, Pseudoalteromonas and Vibrio to the total abundance of Gammaproteobacteria); unclassified Bacteria (difference between the sum of Alphaproteobacteria, Gammaproteobacteria, Bacteroidetes and Actinobacteria to total bacterial abundance as detected by EUB338-I to -III); and unclassified cells (DAPI-stained cells not detected by probes EUB338-I to -III, EURY806, CREN537/ CREN554). In addition, 2-tailed $t$-tests comparing relative and absolute abundances between latitudes and biomes were performed. Abundances were sorted by higher (combining stations from the tropical and subtropical climate zones, 0 to $35^{\circ}$ ) and lower latitudes (temperate and polar zones, $>35^{\circ}$ ), as well as their association with the 4 major oceanic biomes (Longhurst 1998). These are designated the Polar, Coastal, Westerlies and Trades biomes and categorized by oceanographic characteristics, including seasonal cycles of nutrient availability and illumination. Furthermore, Pearson product moment correlation coefficients, $r$, between prokaryotic abundances of bacterial groups, and between prokaryotic abundances and physicochemical parameters, were calculated (Tables S3 to S5 in the supplement at www.int-res.com/ articles/suppl/a061p179_supp.pdf). All reported correlations were statistically significant $(p<0.05)$.

\section{RESULTS}

\section{Environmental parameters}

Highest concentrations of oxygen $\left(>6.5 \mathrm{ml} \mathrm{l}^{-1}\right)$, total inorganic nitrogen $\left(>35 \mu \mathrm{M} \mathrm{l}^{-1}\right)$ and phosphorus $\left(>2 \mu \mathrm{M} \mathrm{l}^{-1}\right)$, nitrate $\left(>20 \mu \mathrm{M} \mathrm{l}^{-1}\right)$, nitrite $\left(>0.3 \mu \mathrm{M} \mathrm{l}^{-1}\right)$, ammonium $\left(>0.28 \mu \mathrm{M} \mathrm{l}^{-1}\right)$ and phosphate $\left(>1 \mu \mathrm{M} \mathrm{l}^{-1}\right)$ were recorded in temperate and cold waters of the Southern Ocean (Table S1). The concentration of silica peaked in Antarctic waters (up to $76 \mu \mathrm{M} \mathrm{l}^{-1}$ ). Elevated nutrient levels were also recorded in the northern Atlantic and in the Benguela (Namibian) and Humboldt (Peruvian) upwelling systems. Temperature ranged from -0.1 (Antarctic Peninsula) to $30.1^{\circ} \mathrm{C}$ (Solomon Islands), and its negative correlation with nutrients, oxygen, as well as chlorophyll $a$ and in vivo fluorescence (indicators of phytoplankton biomass), confirmed colder waters as being nutrient richer, more aerated and more productive ( $r$ between -0.42 and $-0.86)$. The chlorophyll a concentration peaked in the pelagic Indian Ocean $\left(1.6 \mu \mathrm{g} \mathrm{l}^{-1}\right)$ and the Benguela upwelling system $\left(1.2 \mu \mathrm{g} \mathrm{l}^{-1}\right)$. Solar radiation as a mean of photosynthetically active radiation (PAR) and surface PAR (SPAR) was highest in several subtropical and tropical locations (>630 and $>2500 \mu \mathrm{M}$ photons $\mathrm{m}^{-2} \mathrm{~s}^{-2}$, respectively). 


\section{Abundance of major bacterioplankton groups}

Relative fractions of Bacteria as detected by probe mix EUB338 ranged from $65 \%$ (Stn 21; Caribbean Sea) to $88 \%$ (Stn 17; Antarctic Peninsula) of DAPI-stained cells upon cell permeabilization with lysozyme, with variations in absolute numbers between $1 \times 10^{5}$ and $3 \times 10^{6}$ cells $\mathrm{ml}^{-1}$ (Table 1). For 15 out of the 24 stations, the detectability increased between 3 and $14 \%$ (corresponding to $3.3 \times 10^{3}$ and $5.4 \times 10^{5}$ cells $\mathrm{ml}^{-1}$ ) upon cell permeabilization with both achromopeptidase and lysozyme. Archaea were only detected at 11 out of the 24 stations, most of them in the southern hemisphere, with relative fractions $>1 \%$ occurring at only 5 locations.

Alphaproteobacteria, Gammaproteobacteria and Bacteroidetes constituted the major fraction of surface bacterioplankton around the globe (Fig. 1, Table 1). Their combined relative abundance accounted for up to $72 \%$ (globally averaged $63 \%$ ) of DAPI-stained cells, and up to $93 \%$ (averaged $81 \%$ ) of cells detected by EUB338 (average detectability of lysozyme and combined lysozyme/achromopeptidase permeabilization). At 2 out of 5 polar stations (South Greenland and Antarctic Ocean) Actinobacteria represented a considerable fraction with 10 and $12 \%$, respectively. Their lowest relative abundances (approximately 1.5\%) occurred at pelagic stations in the Atlantic, Indian and Southern Oceans, resulting in an average relative fraction of $4.5 \%$.

Alphaproteobacteria were the most abundant group across all samples, with relative abundances between $29 \%$ (Stn 13; Solomon Islands) and $44 \%$ (Stn 3; West Greenland) and a global average of $37 \%$. Absolute alphaproteobacterial cell numbers varied between $3.9 \times 10^{4}$ and $1.8 \times 10^{6} \mathrm{ml}^{-1}$, with a global average of $3.7 \times 10^{5} \mathrm{ml}^{-1}$. The SAR11 clade, a subclass of Alphaproteobacteria, constituted between 24 and $41 \%$ (average $30 \%$ ) and therefore represented the majority of surface water Alphaproteobacteria. The relative abundance of Gammaproteobacteria was highest (19 to $20 \%$ ) at Stns 10, 16 and 17 (NW Australia, Antarctica) and lowest $(6 \%)$ at Stn 15 (Southern Ocean), globally averaging $14 \%$. The SAR86 clade, a subclass of Gammaproteobacteria, constituted between 1\% (Stn 15; Southern Ocean) and 9\% (Stns 7 and 17; Benguela upwelling and Antarctic Peninsula), with a global average of $4.6 \%$. Bacteroidetes outnumbered Gammaproteobacteria at several stations, but had a lower average relative abundance (12\%) due to their more patchy distribution, which varied between $3 \%$ (Stn 9; NW Australia) and 20\% (Stn 7; Benguela upwelling). The absolute abundance of Bacteroidetes, however, was, on a global average, slightly higher (1.3 $\times 10^{5}$ cells ml ${ }^{-1}$ ) than that of Gammaproteobacteria $(1.2$ $\times 10^{5}$ cells $\mathrm{ml}^{-1}$ ). This highlighted that absolute cell numbers did not always reflect relative abundances. While, for instance, the relative Bacteroidetes abundance at Stns 3 and 4 varied by only $0.7 \%$, actual cell numbers were 16 -fold different $\left(6.4 \times 10^{5}\right.$ compared to $3.9 \times 10^{4}$ cells ml${ }^{-1}$ ).

Pseudoalteromonas, Vibrio and the Roseobacter clade were detected ubiquitously (Table 1). The Roseobacter clade (Alphaproteobacteria) was most abundant in the Caribbean Sea (Stn 21; 8.2\%) and least at equatorial Africa (Stn $6 ; 1.5 \%$ ), globally averaging $3.8 \%$ corresponding to $3.5 \times 10^{4} \mathrm{cells} \mathrm{ml}^{-1}$. Pseudoalteromonas (Gammaproteobacteria) was most abundant at the Antarctic Peninsula (Stn 17;6\%) and least at South Australia (Stns 11 and 12; 0.5\%), globally averaging $2.6 \%\left(2.1 \times 10^{4}\right.$ cells $\left.\mathrm{ml}^{-1}\right)$. The abundance of Vibrio (Gammaproteobacteria) peaked at equatorial Africa (Stn 6; 3.2\%), while being lowest in the Azores and Caribbean Sea (Stns 4 and 21; 0.3\%), globally averaging $1.5 \%\left(1.3 \times 10^{4} \mathrm{cells} \mathrm{m}^{-1}\right)$.

\section{Biogeographical patterns of bacterial distribution}

PCA comparing relative bacterial abundances between all 24 stations showed 2 clusters, while Stns 9 (NW Australia), 13 (Solomon Islands) and 17 (Antarctic Peninsula) were positioned separately (Fig. 2). The 2 clusters corresponded to the Earth's colder and warmer climate zones comprising stations from higher $\left(>35^{\circ}\right.$; temperate and polar zone) and lower latitudes ( 0 to $35^{\circ}$; tropical and subtropical zone), respectively. Four stations (Stns 7, 10, 15 and 24) did not fit the pattern and were positioned in the opposite latitude cluster. Stn 7 is located in the Benguela upwelling system, the colder, nutrient-rich waters of which probably yielded a community structure similar to colder oceans despite the subtropical location. The exclusion of Stn 10 (NW Australia) from the pattern cannot be related to an obvious factor, but was potentially due to unique oceanographic characteristics that also resulted in the entirely separate positioning of its 'sister station' Stn 9. Stns 15 (Southern Ocean) and 24 (northern Sargasso Sea) are located in regions where colder and warmer climates meet, and the opposite positioning probably reflected the fact that those communities were sampled at a transition between colder and warmer waters. PCA with absolute abundances yielded a similar latitudinal grouping of stations, albeit being less distinct as with relative values (data not shown).

PCA demonstrated that the relative abundances of Bacteroidetes and unclassified Bacteria (cells detected by probe mix EUB338, but not by ALF968, GAM42a, CF319a, or HGC69a) accounted most for the latitudinal pattern. This was consistent with significantly different relative fractions of Bacteroidetes (peaking at higher lat- 


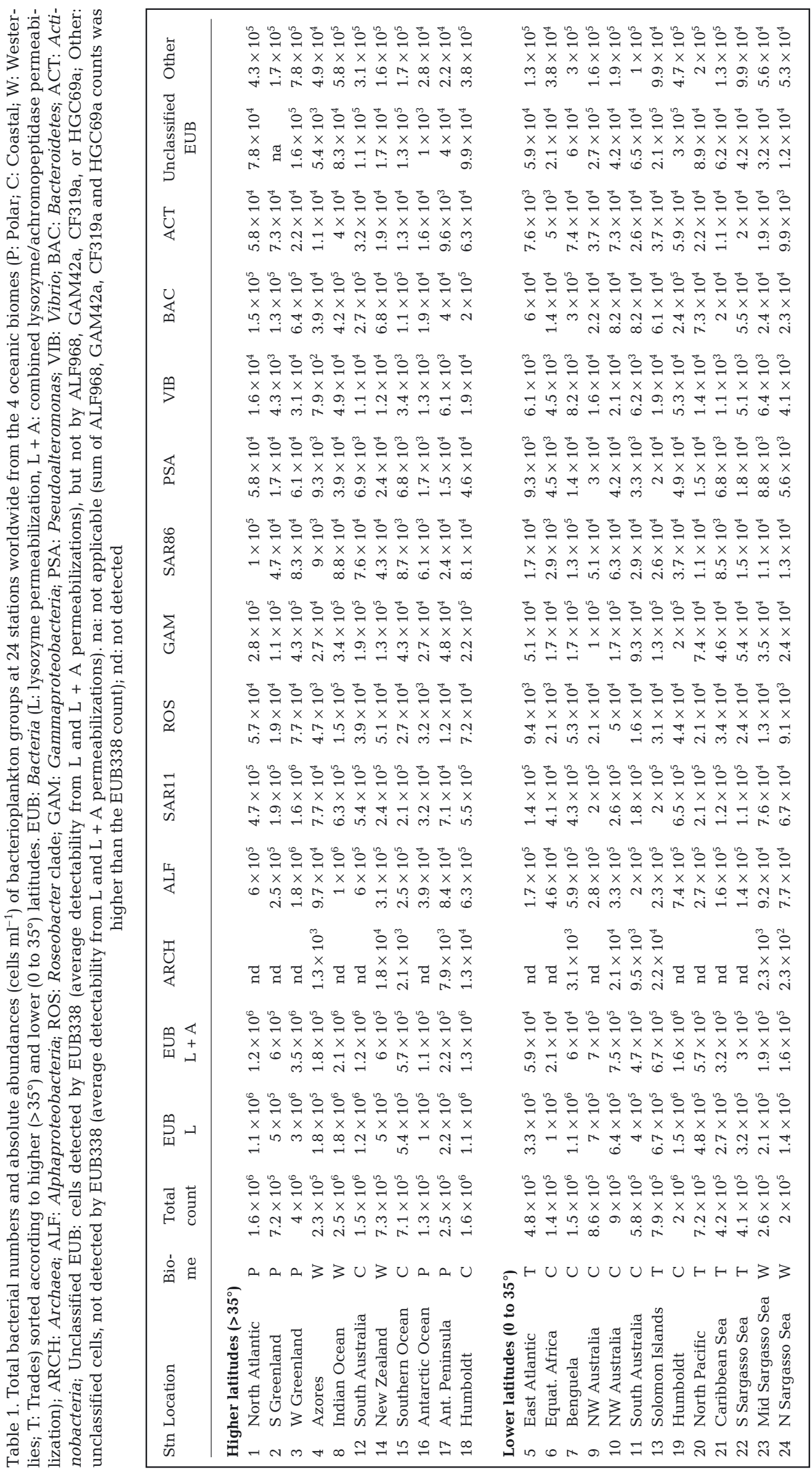




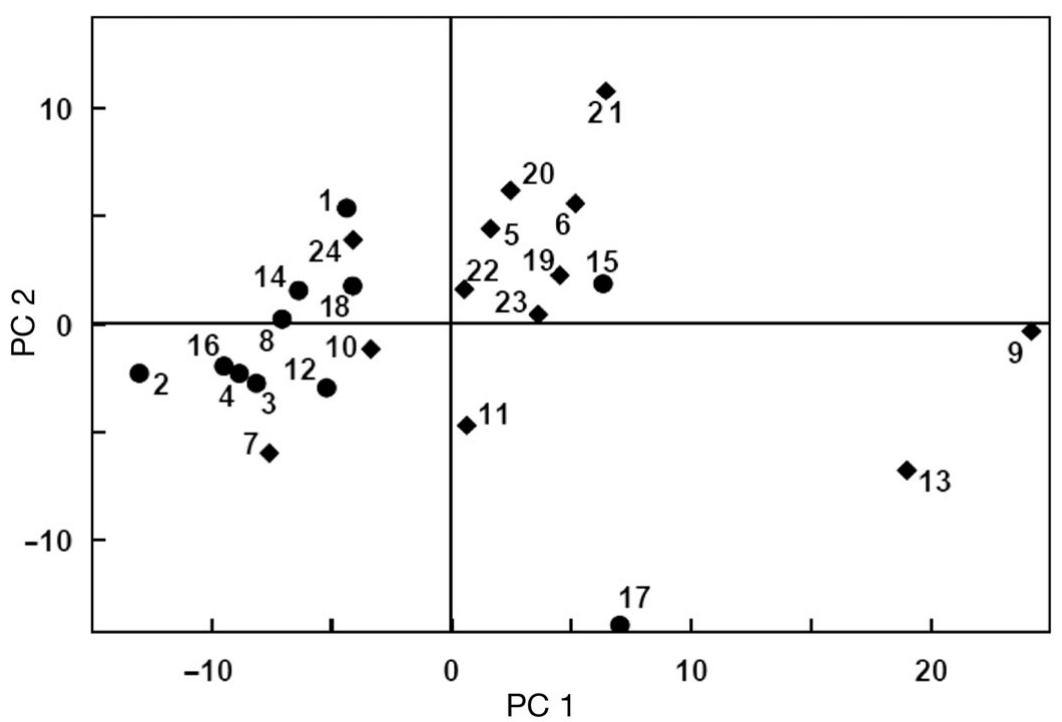

Fig. 2. Principal Component (PC) 2 versus 1 scores comparing relative bacterial abundances between 24 stations worldwide showing 2 clusters comprising samples from higher $(\bullet)$ and lower $(\diamond)$ latitudes, respectively. The principal components explain 51 and $17 \%$, respectively, of the total variance between stations

Table 2. Pearson product moment correlation coefficients $(r)$ between environmental parameters and absolute abundances of bacterioplankton groups. ALF: Alphaproteobacteria; ROS: Roseobacter clade; GAM: Gammaproteobacteria; BAC: Bacteroidetes; ACT: Actinobacteria; chl-a: chlorophyll $a_{i} \mathrm{O}_{2}$ sat: oxygen saturation. Black: global correlations, blue: correlations at higher $\left(>35^{\circ}\right)$ latitudes, red: correlations at lower $\left(0\right.$ to $\left.35^{\circ}\right)$ latitudes

\begin{tabular}{|llllllll|}
\hline & ALF & SAR11 & ROS & GAM & SAR86 & BAC & ACT \\
\hline $\mathrm{NO}_{2}$ & 0.78 & 0.71 & 0.62 & 0.62 & 0.82 & 0.94 & 0.66 \\
$\mathrm{NO}_{3}$ & 0.58 & & & & 0.79 & 0.8 & 0.54 \\
$\mathrm{PO}_{4}$ & 0.9 & 0.84 & 0.7 & 0.78 & 0.83 & 0.96 & 0.78 \\
$\mathrm{SiO}_{2}$ & 0.61 & & 0.74 & 0.66 & 0.97 & 0.72 & 0.81 \\
chl-a & & & 0.47 & & 0.38 & 0.67 & \\
& & & & & 0.81 & & \\
$\mathrm{O}_{2}$ sat & -0.65 & -0.68 & & -0.64 & -0.5 & -0.62 & -0.74 \\
& -0.65 & -0.69 & & -0.65 & -0.61 & -0.63 & -0.76 \\
\hline
\end{tabular}

Table 3. Pearson product moment correlation coefficients $(r)$ between environmental parameters and relative abundances of bacterioplankton groups. ALF: Alphaproteobacteria; BAC: Bacteroidetes; Temp: temperature; Total N: total inorganic nitrogen; chl-a: chlorophyll $a_{;} \mathrm{O}_{2} \mathrm{C}$ : oxygen concentration. Black: global correlations, blue: correlations at higher $\left(>35^{\circ}\right)$ latitudes, red: correlations at lower $\left(0\right.$ to $\left.35^{\circ}\right)$ latitudes

\begin{tabular}{|lrcr|}
\hline & ALF & SAR86 & BAC \\
\hline Temp & 0.72 & -0.53 & -0.64 \\
& -0.61 & & -0.75 \\
Total N & -0.74 & 0.49 & 0.39 \\
$\mathrm{NO}_{2}$ & -0.84 & & 0.45 \\
& 0.55 & & 0.68 \\
$\mathrm{NO}_{3}$ & -0.85 & 0.38 & 0.39 \\
& 0.59 & & 0.66 \\
$\mathrm{PO}_{4}$ & -0.81 & 0.4 & 0.56 \\
chl-a & 0.54 & 0.65 & 0.47 \\
$\mathrm{O}_{2} \mathrm{C}$ & -0.85 & 0.6 & 0.79 \\
& 0.53 & & \\
\hline
\end{tabular}

itudes; $\mathrm{p}=0.015$ ) and unclassified Bacteria (peaking at lower latitudes; $\mathrm{p}=0.034$ ) between colder and warmer oceans. Also Vibrio showed latitudinal variation (peaking at lower latitudes; $\mathrm{p}=0.039$ ). Comparison between biomes revealed relative abundances of Alphaproteobacteria peaking in the Westerlies biome ( $\mathrm{p}=0.023)$ and of Gammaproteobacteria in the Polar biome $(\mathrm{p}=$ 0.028). For Roseobacter relative abundances were highest in subtropical and tropical locations ( $p=0.027$ ), while absolute abundances peaked in temperate and polar waters $(\mathrm{p}=0.041)$.

\section{Relation of community structure to environmental parameters}

Linkages of bacterial distribution with environmental parameters were analyzed by PCA and Pearson product moment correlations. PCA, being a multivariate analysis comparing all parameters, provides insights into more complex correlations and interdependencies. In contrast, Pearson correlations point out direct pairwise associations between abundances and physicochemical parameters (Tables 2 \& 3, Tables S4 \& S5) and/or between bacterial groups with a comparable response to environmental conditions (Table S3). Both approaches revealed relations of community structure to environmental parameters, with distinct variations depending on whether the analysis was done using relative or absolute bacterial abundances. Absolute abundances of most bacterial groups showed a latitude-dependent pattern, being correlated with nutrient concentrations in warmer, but with oxygen saturation in colder oceans (Tables $2 \&$ S4). PCA highlighted these associations by positioning oxygen saturation and bacterial abundances opposite each other, and nutrients and bacterial abundances at similar positions on the abscissa (Fig. 3a). Absolute cell numbers of Roseobacter and SAR86 were globally correlated with chlorophyll a (Table 2). The influence of environmental parameters on relative abundances was more complex. While PCA clustered SAR86 with nitrogenous and phosphorous nutrients, Actinobacteria with chlorophyll $a$, ammonium and nitrite, and Roseobacter with solar radiation, salinity and oxygen saturation (Fig. 3b), only the first was reflected in Pearson correlations. In 


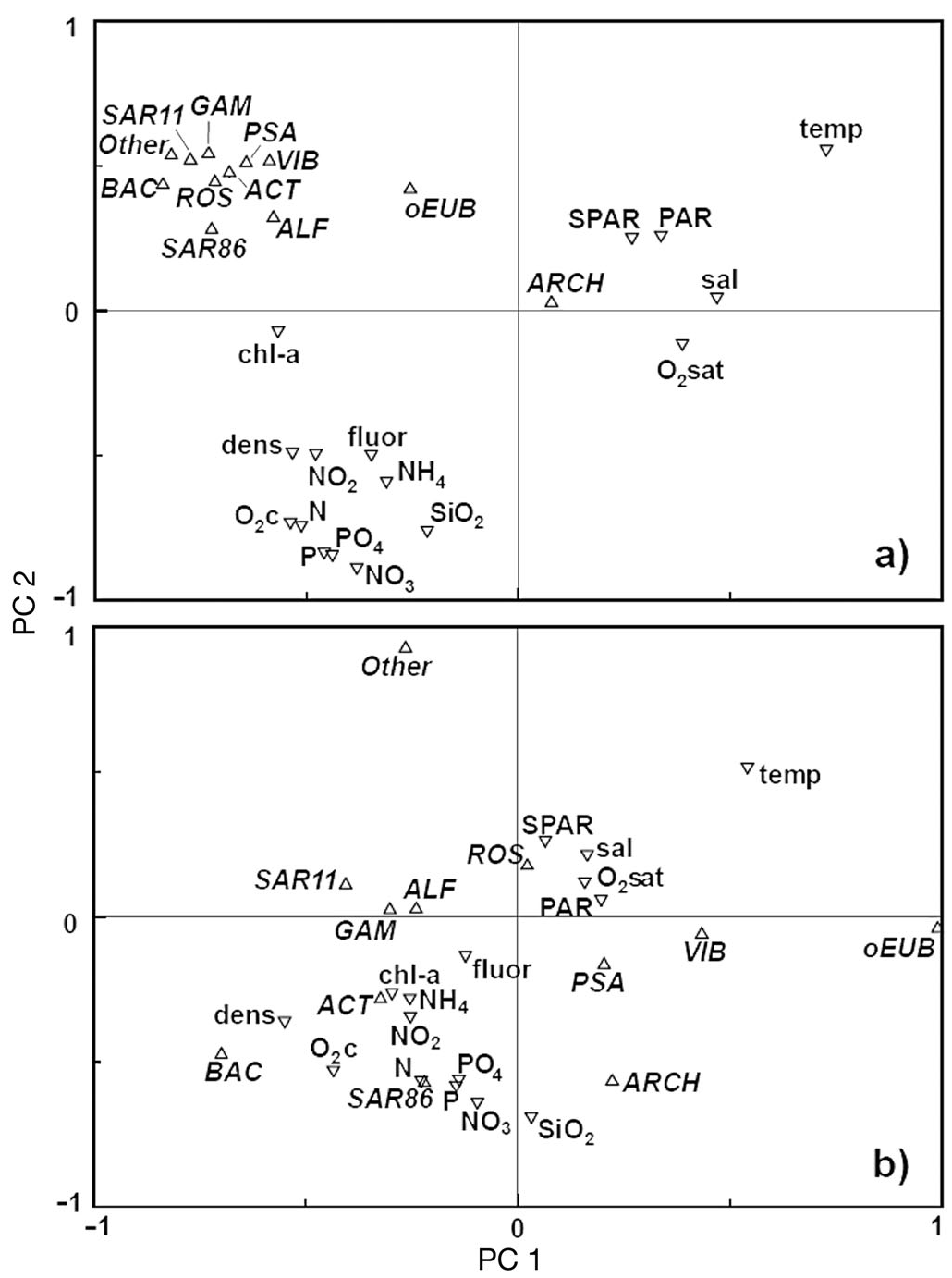

Fig. 3. Principal Component (PC) 2 versus 1 correlation loadings comparing environmental parameters $(\nabla)$ with (a) absolute and (b) relative bacterial abundances $(\Delta)$ between 24 stations worldwide. The principal components explain (a) 30 and $28 \%$ and (b) 46 and $17 \%$ of the total variance between samples. ARCH: Archaea; ALF: Alphaproteobacteria; ROS: Roseobacter clade; GAM: Gammaproteobacteria; PSA: Pseudoalteromonas; VIB: Vibrio; BAC: Bacteroidetes; ACT: Actinobacteria; oEUB: unclassified Bacteria detected by EUB338, but not by ALF968, GAM42a, CF319a, or HGC69a; Other: unclassified cells not detected by EUB338. All EUB338 fractions refer to the average detectability from lysozyme and combined lysozyme/ achromopeptidase permeabilizations. temp: temperature; sal: salinity; dens: density; $\mathrm{N}$ : total inorganic nitrogen; $\mathrm{P}$ : total inorganic phosphorus; chl-a: chlorophyll $a_{i}$ fluor: in vivo fluorescence; $\mathrm{O}_{2} \mathrm{C}$ : oxygen concentration $\mathrm{O}_{2}$ sat: oxygen saturation; PAR: photosynthetically active radiation; SPAR: surface PAR

contrast, the global associations of Bacteroidetes with chlorophyll $a$ and different inorganic nutrients were only seen in Pearson correlations (Tables 3 \& S5). Several correlations were restricted to either higher or lower latitudes. Furthermore, 4 out of 10 found associations of Alphaproteobacteria with environmental parameters differed between colder and warmer waters, having a positive correlation at higher, but a negative correlation at lower latitudes and vice versa (Table 3 ).

\section{DISCUSSION}

The present study adds to recent largescale surveys of marine bacterial community structure in surface seawater (Baldwin et al. 2005, Pommier et al. 2007, Fuhrman et al. 2008, Biers et al. 2009) by presenting a quantitative in situ dimension of marine bacterioplankton around the world. We confirmed the ubiquitous dominance of Alphaproteobacteria and the SAR11 clade (Morris et al. 2002, Pommier et al. 2007), medium to high abundance of Gammaproteobacteria and Bacteroidetes (Giovannoni \& Stingl 2005) and low numbers of Archaea in oceanic surface waters (DeLong et al. 2006). In addition, this is the first quantitative report of Actinobacteria, the SAR86 and Roseobacter clades, and the Pseudoalteromonas and Vibrio genera on a global scale.

In comparison to other CARD-FISH surveys, we reached similar conclusions regarding the relative abundance of higher phylogenetic groups in coastal tropical Atlantic (Baltar et al. 2007) and Antarctic waters (Topping et al. 2006), but found differing fractions of SAR11, Gammaproteobacteria and Bacteroidetes in the Benguela upwelling system (Schattenhofer et al. 2009). This probably reflected the fact that the samplings were conducted in different seasons (boreal autumn versus spring) and at different coordinates $\left(24^{\circ} \mathrm{S}\right.$ versus $\left.30^{\circ} \mathrm{S}\right)$. The Benguela province harbours several, oceanographically distinct upwelling centres. While the present sampling was done in the most intense upwelling zone, which is additionally influenced by the input of aerosol particulates (representing an environmental barrier), Schattenhofer et al. (2009) sampled in a centre and period of minimal upwelling (Longhurst 1998). Seasonal variation plays an important role in bacterial community dynamics, but cannot be addressed here since samplings were only possible at one time point at each station.

The present study provides further evidence for spatial variation in marine bacterioplankton community structure on a global scale. Finding latitude- and biome-related variations in bacterial distribution highlighted the presence of latitudinal patterns among 
marine microbiota (Pommier et al. 2007, Fuhrman et al. 2008) and emphasized that warm water communities are more similar in composition to each other than to cold water communities (Baldwin et al. 2005). Environmental parameters were correlated with both relative and absolute bacterial abundances, indicating a complex interplay of abiotic factors behind the structuring of bacterioplankton communities. The strong influence of nutrient concentrations on bacterial population sizes at lower latitudes probably reflected the characteristic nutrient scarcity in warmer waters. In the richer waters of colder oceans, however, nutrients were likely not limiting; instead, a negative correlation of population sizes with oxygen saturation was found, possibly reflecting the increased oxygen consumption of the larger active bacterial populations.

For Alphaproteobacteria, several correlations with environmental parameters differed between latitudes. We assume that these variations reflected the existence of variable dominant populations, or ecotypes (genetically closely related but physiologically distinct populations with unique niches; Cohan 2002) between colder and warmer waters. Widespread bacterial groups commonly share a high diversity of distinct low-level taxa (Kirchman et al. 2005), and ribotypes from all major bacterioplankton groups were shown to be restricted to either higher or lower latitudes (Pommier et al. 2005). Spatially diverging communities were also observed for Roseobacter (Selje et al. 2004) and Prochlorococcus (Bouman et al. 2006) ecotypes.

The present study highlighted the prevalence of Gammaproteobacteria and Bacteroidetes in colder waters (Malmstrom et al. 2007, Schattenhofer et al. 2009). Furthermore, the Bacteroidetes-chlorophyll a correlation substantiated the group as being responsive to phytoplankton blooms (Fandino et al. 2005, Pommier et al. 2007). It should be considered, however, that any apparent correlation can be a side-effect of uncharacterized, superior dependencies (Levin et al. 2001). Furthermore, bacterial biogeography is likely influenced by more parameters than analyzed here, such as hydrography (Teira et al. 2006, Galand et al. 2010) or carbon-flux related variables (Teira et al. 2008).

The Roseobacter clade, Pseudoalteromonas and Vibrio were quantified to complement results from a culture-based survey of antagonistic bacteria performed during the same expedition, and to provide further insight into the marine ecology of these groups. The Roseobacter clade is a heterogeneous group involved in global sulphur and greenhouse gas cycling (Moran et al. 2003, Wagner-Döbler \& Biebl 2006). While the peak of relative abundances in warmer waters contradicted earlier observations, the finding of significantly higher absolute numbers in colder waters was consis- tent (Selje et al. 2004). The detection of smaller relative Roseobacter fractions than reported elsewhere (Wagner-Döbler \& Biebl 2006) potentially reflected the fact that no samplings were performed during phytoplankton blooms, when the clade often dominates the bacterioplankton. Nevertheless, the global correlation of absolute Roseobacter cell numbers with chlorophyll a underlined the association with algal communities. Pseudoalteromonas spp. is often associated with marine eukaryotes (Holmström \& Kjelleberg 1999) and produces various antibacterial compounds (Bowman 2007). Despite its prevalence on surfaces, we detected a considerable planktonic population, corresponding to findings by Schattenhofer et al. (2009). Vibrio is mainly researched regarding its pathogenicity to humans or aquatic animals (Thompson et al. 2006). The detected fractions of Vibrio were consistent with other studies using a hybridization approach (Heidelberg et al. 2002, Schattenhofer et al. 2009). In contrast, the Global Ocean Survey - a metagenomics-based and hence also quantitative analysis - reported an approximately $1 \%$ smaller abundance (Biers et al. 2009).

In conclusion, the present study provides a global quantitative survey of the major bacterioplankton groups, important clades and 2 bacterial genera in surface seawater around the world. The latitudinal patterns in community structure, together with the clustering and correlations of bacteria with physicochemical parameters, underlined the existence of biogeographical variation among marine bacteria and the relation of abiotic factors to these patterns. The latitude-dependent variations in both relative and absolute bacterial abundances indicated that bacterial biogeography may follow principles similar to those seen for higher eukaryotes.

Acknowledgements. The Carlsberg Foundation and the Danish Center for Food Research (LMC) are thanked for donations covering international travel. Funding from the Programme Committee for Food, Health and Welfare under the Danish Strategic Research Council is acknowledged. We express our thanks to Drs. Jørn Smedsgaard and Kristian Fog Nielsen and Ellen Kirstine Lyhne for assistance in sampling during the expedition. We thank Britta Poulsen for technical assistance in CARD-FISH, Katherine Richardson and Karen Marie Hilligsøe for providing physicochemical data, and Jens Heilmann for help with database management. The present work was carried out as part of the Galathea 3 expedition under the auspices of the Danish Expedition Foundation. This is Galathea 3 Contribution No. P 66.

\section{LITERATURE CITED}

Abell GCJ, Bowman JP (2005) Ecological and biogeographic relationships of class Flavobacteria in the Southern Ocean. FEMS Microbiol Ecol 51:265-277 
Arrigo KR (2005) Marine microorganisms and global nutrient cycles. Nature 437:349-355

Baas-Becking LGM (1934) Geobiologie of inleiding Tot de Milieukunde. WP Van Stockum \& Zoon NV, den Haag

Baldwin AJ, Moss JA, Pakulski JD, Catala P, Joux F, Jeffrey WH (2005) Microbial diversity in a Pacific Ocean transect from the Arctic to Antarctic circles. Aquat Microb Ecol 41:91-102

Baltar F, Arístegui J, Gasol JM, Hernández-León S, Herndl GJ (2007) Strong coast-ocean and surface-depth gradients in prokaryotic assemblage structure and activity in a coastal transition zone region. Aquat Microb Ecol 50: 63-74

> Biers EJ, Sun S, Howard EC (2009) Prokaryotic genomes and diversity in surface ocean waters: interrogating the global ocean sampling metagenome. Appl Environ Microbiol 75: 2221-2229

Bouman HA, Ulloa O, Scanlan DJ, Zwirglmaier K and others (2006) Oceanographic basis of the global surface distribution of Prochlorococcus ecotypes. Science 312:918-921

> Bowman JP (2007) Bioactive compound synthetic capacity and ecological significance of marine bacterial genus Pseudoalteromonas. Mar Drugs 5:220-241

Cohan FM (2002) What are bacterial species? Annu Rev Microbiol 56:457-487

DeLong EF, Preston CM, Mincer T, Rich V and others (2006) Community genomics among stratified microbial assemblages in the ocean's interior. Science 311:496-503

$>$ Dolan JR (2005) Biogeography of aquatic microbes. Aquat Microb Ecol 41:39-48

Fandino LB, Riemann L, Steward GF, Azam F (2005) Population dynamics of Bacteroidetes during marine phytoplankton blooms analyzed by real-time quantitative PCR. Aquat Microb Ecol 40:251-257

Fuhrman JA, Steele JA, Hewson I, Schwalbach MS, Brown MV, Green JL, Brown JH (2008) A latitudinal diversity gradient in planktonic marine bacteria. Proc Natl Acad Sci USA 105:7774-7778

> Galand PE, Potvin M, Casamayor EO, Lovejoy C (2010) Hydrography shapes bacterial biogeography of the deep Arctic Ocean. ISME J 4:564-576

Giovannoni SJ, Stingl U (2005) Molecular diversity and ecology of microbial plankton. Nature 437:343-348

> Gram L, Melchiorsen J, Bruhn JB (2010) Antibacterial activity of marine culturable bacteria collected from a global sampling of ocean surface waters and surface swabs of marine organisms. Mar Biotechnol 12:439-451

- Heidelberg JF, Heidelberg KB, Colwell RR (2002) Seasonality of Chesapeake Bay bacterioplankton species. Appl Environ Microbiol 68:5488-5497

Holmström C, Kjelleberg S (1999) Marine Pseudoalteromonas species are associated with higher organisms and produce biologically active extracellular agents. FEMS Microbiol Ecol 30:285-293

- Kirchman DL, Dittel AI, Malmstrom RR, Cottrell MT (2005) Biogeography of major bacterial groups in the Delaware Estuary. Limnol Oceanogr 50:1697-1706

- Levin LA, Etter RJ, Rex MA, Gooday AJ and others (2001) Environmental influences on regional deep-sea species diversity. Annu Rev Ecol Syst 32:51-93

Longhurst AR (1998) Ecological geography of the sea. Academic Press, San Diego, CA

Ludwig W, Strunk O, Westram R, Richter L and others (2004) ARB: a software environment for sequence data. Nucleic Acids Res 32:1363-1371

Malmstrom RR, Straza TRA, Cottrell MT, Kirchman DL (2007) Diversity, abundance, and biomass production of bacterial groups in the western Arctic Ocean. Aquat Microb Ecol 47:45-55

Martens H, Martens M (2001) Multivariate analysis of quality: an introduction. John Wiley \& Sons, New York, NY

Martiny JBH, Bohannan BJM, Brown JH, Colwell RK and others (2006) Microbial biogeography: putting microorganisms on the map. Nat Rev Microbiol 4:102-112

Moran MA, Gonzalez JM, Kiene RP (2003) Linking a bacterial taxon to sulfur cycling in the sea: studies of the marine Roseobacter group. Geomicrobiol J 20:375-388

> Morris RM, Rappé MS, Connon SA, Vergin KL, Siebold WA, Carlson CA, Giovannoni SJ (2002) SAR11 clade dominates ocean surface bacterioplankton communities. Nature 420: 806-810

Pernthaler A, Pernthaler J, Amann R (2004) Sensitive multicolor fluorescence in situ hybridization for the identification of environmental microorganisms. In: Kowalchuk GA, de Bruijn FJ, Head IM, Akkermans AD, van Elsas J (eds) Molecular microbial ecology manual. Kluwer Academic Publishers, Dordrecht, p 711-726

Pinhassi J, Winding A, Binnerup SJ, Zweifel UL, Riemann B, Hagström $\AA$ (2003) Spatial variability in bacterioplankton community composition at the Skagerrak-Kattegat Front. Mar Ecol Prog Ser 255:1-13

> Pommier T, Pinhassi J, Hagström A (2005) Biogeographic analysis of ribosomal RNA clusters from marine bacterioplankton. Aquat Microb Ecol 41:79-89

Pommier T, Canbäck B, Riemann L, Boström KH and others (2007) Global patterns of diversity and community structure in marine bacterioplankton. Mol Ecol 16:867-880

Pruesse E, Quast C, Knittel K, Fuchs B, Ludwig W, Peplies J, Glöckner FO (2007) SILVA: a comprehensive online resource for quality checked and aligned ribosomal RNA sequence data compatible with ARB. Nucleic Acids Res 35:7188-7196

Rusch DB, Halpern AL, Sutton G, Heidelberg KB and others (2007) The Sorcerer II Global Ocean Sampling expedition: Northwest Atlantic through eastern tropical Pacific. PLoS Biol 5:e77

Schattenhofer M, Fuchs BM, Amann R, Zubkov MV, Tarran GA, Pernthaler J (2009) Latitudinal distribution of prokaryotic picoplankton populations in the Atlantic Ocean. Environ Microbiol 11:2078-2093

Sekar R, Pernthaler A, Pernthaler J, Warnecke F, Posch T, Amann R (2003) An improved protocol for quantification of freshwater Actinobacteria by fluorescence in situ hybridization. Appl Environ Microbiol 69:2928-2935

- Sekiguchi H, Watanabe M, Nakahara T, Xu B, Uchiyama H (2002) Succession of bacterial community structure along the Changjiang River determined by denaturing gradient gel electrophoresis and clone library analysis. Appl Environ Microbiol 68:5142-5150

Selje N, Simon M, Brinkhoff T (2004) A newly discovered Roseobacter cluster in temperate and polar oceans. Nature 427:445-448

Skovhus TL, Holmström C, Kjelleberg S, Dahllöf I (2007) Molecular investigation of the distribution, abundance and diversity of the genus Pseudoalteromonas in marine samples. FEMS Microbiol Ecol 61:348-361

Taniguchi A, Hamasaki K (2008) Community structures of actively growing bacteria shift along a north-south transect in the western North Pacific. Environ Microbiol 10:1007-1017

- Teira E, Reinthaler T, Pernthaler A, Pernthaler J, Herndl GJ (2004) Combining catalyzed reporter depositionfluorescence in situ hybridization and microautoradiography to detect substrate utilization by Bacteria and 
Archaea in the deep ocean. Appl Environ Microbiol 70 : 4411-4414

Teira E, Lebaron P, van Aken H, Herndl GJ (2006) Distribution and activity of Bacteria and Archaea in the deep water masses of the North Atlantic. Limnol Oceanogr 51:2131-2144

Teira E, Gasol JP, Aranguren-Gassis M, Fernández A, González J, Lekunberri I, Antón Álvarez-Salgado X (2008) Linkages between bacterioplankton community composition, heterotrophic carbon cycling and environmental conditions in a highly dynamic coastal ecosystem. Environ Microbiol 10:906-917

Editorial responsibility: Jed Fuhrman,

Los Angeles, California, USA
Thompson FL, Austin B, Swings J (2006) The biology of Vibrios. ASM Press, Washington, DC

Topping JN, Heywood JL, Ward P, Zubkov MV (2006) Bacterioplankton composition in the Scotia Sea, Antarctica, during the austral summer of 2003. Aquat Microb Ecol 45: 229-235

> Van der Gucht K, Cottenie K, Muylaert K, Vloemans N and others (2007) The power of species sorting: local factors drive bacterial community composition over a wide range of spatial scales. Proc Natl Acad Sci USA 104:20404-20409

Wagner-Döbler I, Biebl H (2006) Environmental biology of the marine Roseobacter lineage. Annu Rev Microbiol 60: $255-280$

Submitted: February 10, 2010; Accepted: August 4, 2010 Proofs received from author(s): September 28, 2010 